\title{
SERODIAGNOSIS OF BOVINE NEOSPOROSIS IN MOSUL CITY, IRAQ
}

\author{
MAAB I. AL-FARWACHI; OMER KH. AL-HANKAWE and WISAM S. AL KHAFAJI
}

Department of Internal and preventive Medicine, College of veterinary medicine University of Mosul, Mosul, Iraq.

\section{ABSTRACT}

Received at: $30 / 5 / 2012$

Accepted: 1/7/2012
One hundred and eighty four sera of local breed cattle in Mosul city , Iraq were collected for serodiagnosis of neosporosis by indirect enzyme linked immunosorbent assay (Indirect ELISA). The total percentage of seropositive was $17.4 \%$ (32 \184), while the percentages of Neospora caninum antibodies were $12.9,13.1$, and 26.2 in (62) healthy non pregnant animals, (61) aborted cows and (61) pregnant cows respectively. This is the first study with regards to serodiagnosis of neosporosis in cattle in Mosul city, Iraq.

Key words : Neosporosis, Serology, Bovine.

\section{INTRODUCTION}

Neospora caninum is a heteroxenous cyst forming Dubey (2003), that was first recognized in dogs in 1984 (Bjerkas et al., 1984). and was described as a new genus Neospora, type species Neospora caninum in 1988 (Dubey et al., 1988). Cattle and other ungulates such as sheep, goats, horses, white - tailed deer, camels and water buffaloes may act as natural intermediate hosts (Dubey, 2003; Rodrigues et al., 2004 ; Chavez-Velsquez et al., 2004). Canids such as dogs are the definitive host (McAllister et al., 1998). This parasite is new recognized as an important cause of reproductive problems and abortion in dairy and beef cattle worldwide (Dubey, 2003; Dubey et al., 2006). Infection in cattle is transmitted either transplacentally or by ingestion of sporozoite containing oocysts shed by definitive host (Gondim et al., 2004 ).

Generally, the diagnosis of Neospora caninum associated abortion has relied on the histological examination of infected fetuses (Dubey et al., 2006). Other methods used to study Neospora caninum include isolation of the parasite in cell culture (Lei et al., 2005), an indirect fluorescent antibody test on various body fluid (Rahman et al., 2011), immunohistochemistry (Boger and Hattel, 2003) and a variety of enzyme linked immunosorbent assay (Jenkins et al., 2005; Gaturaga et al., 2005). The detection of specific anti-neospora caninum antibodies in sera of cows has been useful for the diagnosis of disease and may also prove suitable for seroepidemiologic investigations (Koiwai et al., 2005; Nourollahi et al., 2008; Alan et al., 2011), therefore, this is the first study to investigate the serodiagnosis of bovine neosporosis in Mosul, Iraq.

\section{MATERIALS and METHODS}

A total of 184 sera (62 sera from healthy non pregnant cows, 61 sera from aborted animals and 61 sera from pregnant cows) were collected from local breed cattle
( 3 - 10 years old ) from different regions in the Mosul city, Iraq during the period from July 2011 to April 2012.

A commercial ELISA kit (Bio - X Neospora caninum, Indirect ELISA kits) for detection of antibodies against Neospora caninum in bovine serum was used, the kit has been supplied from Bio - x Diagnostics Belgium. The test uses 96- well microtitration plates sensitized by a purified Neospora caninum protein. The plates odd columns (1,3,5, 7, 9 and 11) contain the purified protein, where as the even columns (2, 4, $6,8,10,12)$ contain a control antigen. We thus have agenuine negative control. Using such a control reduce the number of false positive considerably.

All sera were tested according to the manufacturers instructions, then read the optical densities in the microwells using a microplate reader at a wave length of $450 \mathrm{~nm}$. ELISA optical density (OD) reading were transformed to serum / positive percentage ( $\mathrm{S} / \mathrm{P}$ ) according to a specific equation cited by manufacturer. The sample considered positive if it gives $\mathrm{S} / \mathrm{P} \%>15 \%, 10 \%<\mathrm{S} / \mathrm{P} \%<15 \%$ considered doubtful, but $\mathrm{S} / \mathrm{P} \%<10 \%$ considered negative.

\section{S / P = Delta OD sample / Delta OD positive X 100}

The data management and statistical analysis by two ways analysis of variance were performed using SPSS version 11.5 (2002) software for windows.

\section{RESULTS}

The results of study showed that the total percentage of seropositive of Neospora caninum antibodies was 17.4 ( mean 32 seropositive out of 184 sera ). Among the 61 pregnant cows, 16 sera $(26.2 \%)$ were seropositive, where as among 61 aborted cows, 8 sera $(13.1 \%)$ were seropositive. Of the 62 healthy non pregnant cows, $8(12.9 \%)$ were seropositive (Table1).

The percentage of seropositive values (S / P \%) was significantly higher in the aborted animals than in other animals (Table 2). 
$\underline{\text { Assiut Vet. Med. J. Vol. } 58 \text { No. } 134 \text { July } 2012}$

Table 1: Percentages of seropositive of bovine neosporosis in Mosul, Iraq

\begin{tabular}{ccc}
\hline Origin of examined sera & Number of sera tested & Number of seropositive (\%) \\
\hline From pregnant cows & 61 & $16 / 61(26.2)$ \\
\hline From aborted cows & 61 & $8 / 61(13.1)$ \\
\hline From healthy non pregnant cows & 62 & $8 / 62(12.9)$ \\
\hline Total & 184 & $32 / 184(17.4)$ \\
\hline
\end{tabular}

Table 2: Distribution of the percentage of serum / positive ( S/ P \% ) values for Neospora caninum seropositive cows

\begin{tabular}{cc}
\hline Origin of examined sera & $\%$ of serum / positive \\
\hline From pregnant cows & $32.8 \pm 2.3^{*}$ \\
\hline From aborted cows & $126.3 \pm 7.2$ \\
\hline From healthy non pregnant cows & $23.5 \pm 2.0$ \\
\hline $\begin{array}{l}\text { * Values expressed as ( Mean } \pm \text { S.E). } \\
\text { Significantly at } \mathrm{p}<0.05 .\end{array}$
\end{tabular}

\section{DISCUSSION}

This is the first serodiagnosis of bovine neosporosis in the Mosul city, Iraq. In this study an antibodies against Neospora caninum was detected in the 32 of 184 sera. Serological surveys indicate wide spread exposure to Neospora caninum in dairy and beef herds in many parts of the world (Anderson et al., 2000).

The seroprevalence of neosporosis in cattle varies depending on the country and region under study (Rahman et al., 2011; Koiwai et al., 2005; Nourollahi et al., 2008; Akca et al., 2005), while there is no published information on the epidemiology of Neospora caninum in cattle in Mosul city, although many authors observed many serological studies of canine and bovine neosporosis in the local countries as Iran (Nourollahi et al., 2008; Akca et al., 2010; Malmasi et al., 2007; Haddadzadeh et al., 2007) and Turkey (Alan et al., 2011; Akca et al., 2005; Kurtdede et al., 2006; Oncel and Biyikologlu, 2003; Simsek et al., 2008).

In our study serodiagnosis of bovine neosporosis based on the results of the indirect ELISA test. This diagnosis of neosporosis in the live animal can be achieved by detection of anti - Neospora caninum antibodies using different serological tests, but ELISA is an approved serological test (Von Blumroder et al., 2004). ELISA is the most suitable for high through put screening of antibodies to parasites, that has been used in epidemiological studies to estimate the prevalence of Neospora caninum infection and to examine the relationship between exposure to Neospora caninum and abortion, milk yield and culling in cattle (Hernandez et al., 2002). Some researches have recommended that the serological status of the herd be determined to obtain information about the risk of abortion and attributable to Neospora caninum infection.

In this study the percentages of seropositive were $12.9,13.1$ and $26.2 \%$ in the healthy non pregnant animals, aborted cows and pregnant cows respectively. Review of all published data indicate that Neospora caninum is a primary abortifacient in cattle (Dubey, 2003; Dubey et al., 2006) and Neospora caninum infection is generally latent and asymptomatic in non pregnant cattle, although bovine neosporosis in pregnant cow is associated with repeated abortion and birth of clinically healthy but persistently infected calves (Buxton et al., 2002).

Several studies demonstrate that chronically infected seropositive cows have an about two - to three fold increased risk of abortion compared to seronegative dams (Pare et al., 1997 ; Wouda et al., 1998; Pfeiffer et al., 2002). Thurmond and Hietala (1997) observed a 7.4 -fold higher risk of abortion during the first gestation of congenitally infected heifers.

The percentage of seropositive values was significantly higher in the aborted animals than in other animals which reflect the high concentration of antibodies against neosporosis, as also in the previous serological studies showed the aborted dams from herd with endemic bovine abortion have higher antibodies against specific antigens (Schares et al., 2000). Other researcher has also shown that the high antibody titer are found in post abortion sera and 
during the second part of pregnancy (Schares et al., 2000; Quintanilla-Gozalo et al., 2000).

In conclusion, this the first report of serodiagnosis of bovine neosporosis in Mosul, Iraq, however, futher epidemiological studies are needed to provide a better understanding of neosporosis under local conditions.

\section{REFERENCES}

Akca, A.; Gokce, H.I.; Guy, C.S.; McGarry, J.W. and Williams, D.J.L. (2005): Prevalence of antibodies to Neospora caninum in local and imported cattle breeds in the Kars province of Turkey. Res. Vet. Sci, 78: 123-126.

Akca, N.; Haddadzadeh, H.R.; Shayan, P.; Vodjgani, M. and Bolourchi, M. (2010): Serological study of Neospora caninum in pregnant dairy cattle in Tehran, Iran. Int. J. Vet. Res. 4 (2): 113-116.

Alan, M.; Cetin, Y.; Sendag, S.; Akkan, H.A. and Karaca, M. (2011): Seroprevalence of antibodies against Neospora caninum in cows in Van Province. Kafak Univ. Vet. Fak. Derg. 17(5): 767-771.

Anderson, M.L.; Andrianarivo, A.G. and Conrad, P.A. (2000): Neosporosis in cattle. Animal Reproduction Science, 60-61, 417-431.

Bjerkas, I.; Mohn, S.F. and Presthus, J. (1984): Unidentified cyst forming protozoon causing encephalomyelitis and myositis in dogs. Z Parasitenkd. 70: 271-274.

Boger, L.A. and Hattel, A.L. (2003): Additional evaluation of undiagnosed bovine abortions cases may reveal fetal neosporosis. Vet. Prarsitol. 113, 1-6.

Buxton, D.; McAllister, M.M. and Dubey, J.P. (2002): The comparative pathogenesis of neosporosis. Trends in Parasitology, 18, 546-552.

Chavez-Velsquez, A.; lvarez-Garca, G.; CollantesFernndez E.; Casas-Astos, E.; RosadioAlcntara, R..; Serrano-Martnez, E. and OrtegaMora, L.M. (2004): First report of Neospora caninum infection in adult alpacas (Vicugna pacos) and llamas (Lama glama). Journal of Parasitology, 90, 864-866.

Dubey, J.P. (2003): Review of Neospora caninum and neosporosis in animals. Korean Journal of Parasitology, 41: 1-16.

Dubey, J.P.; Buxton, D. and Wouda, W. (2006): Pathogenesis of bovine neosporosis. J. Comp. Pathol. 134: 267-289.

Dubey, J.P.; Hattel, A.L.; Lindsay, D.S. and Topper, M.J. (1988): Neonatal Neospora caninum infection in dogs: isolation of the causative agent and experimental transmission. J. Am. Vet. Med. Assoc. 193: 1259-1263.

Gaturaga, I.; Chahan, B.; Xuan, X.; Huang, X.; Liao, M.; Fukumoto, S.; Hirata, H.; Nishikawa, Y.; Takashima, Y.; Suzuki, H.; Fujisaki, K. and Sugimoto, C. (2005): Detection of antibodies to Neospora caninum in cattle by enzyme-linked immunosorbent assay with truncated NcSR2 expressed in Escherichia coli. J. Parasitol. 91: 191-192.

Gondim, L.F.P.; McAllister, M.M.; AndersonSprecher, R.C.; Björkman, C.; Lock, T.F.; Firkins, L.D.; Gao, L. and Fischer, W.R. (2004): Transplacental transmission and abortion in cows administered Neospora caninum oocysts. J of Parasitol, 90: 1394-1400.

Haddadzadeh, H.R.; Sadrebazzaz, A.; Malmasi, A.; Talei Ardakani, A.; Khazraii Nia, P. and Sadreshirazi, N. (2007): Seroprevalence of infection in dogs from rural and urban environments in Tehran, Iran. Parasitol. Res. 101: 1563-5.

Hernandez, J.; Risco, C. and Donovan, A. (2002): Risk of abortion associated with during different lactations and evidence of congenital transmission in dairy cows. J. Am. Vet. Med. Ass. 221: 1742-1746.

Jenkins, M.C.; Fetterer, R.; Schares, G.; Björkman, C.; Wapenaar, W.; McAllister, M. and Dubey, J.P. (2005): HPLC purification of recombinant NCGRA6 antigen improves enzyme-linked immunosorbent assay for serodiagnosis of bovine neosporosis. Vet. Parasitol. 131: 227-234.

Koiwai, M.; Hamaoka, T.; Haritani, M.; Shimizu, S.; Kimura, K. and Yamane, I. (2005): Proportion of abortions due to neosporosis among dairy cattle in Japan. J. Vet. Med. Sci. 67: 1173-1175.

Kurtdede, A.; Kuplulu, S.; Ural, K.; Cingi, C.C.; Guzel, M.; Karakurum, M.C. and Haydardedeoglu, A.E. (2006): Serodiagnosis of bovine neosporosis with immunocomb assay in Ankara region. Ankara Univ. Vet. Fak. Derg, 53: 207-209.

Lei, Y.; Davey, M. and Ellis, J.T. (2005): Attachment and invasion of Toxoplasma gondii and Neospora caninum to epithelial and fibroblast cell lines in vitro. Parasitology 131: 583-590.

Malmasi, A.; Hosseininejad, M.; Haddadzadeh, H.; Badii, A. and Bahonar, A. (2007): Serologic study of anti-antibodies in household dogs and dogs living in dairy and beef cattle farms in Tehran, Iran. Parasitol. Res. 100: 1143-1145.

McAllister, M.M.; Dubey, J.P.; Lindsay, D.S.; Jolley, W.R.; Wills, R.A. and McGuire, A.M. (1998): Rapid communications: dogs are definitive hosts of Neospora caninum. Int. J. Parasitol., 28: 1473-1478.

Nourollahi, F.S.R.; Khalili, M. and Aminzadeh, A.(2008): Prevalence of antibodies to Neospora caninum in cattle in Kerman province, South East Iran. Vet. Arhiv. 78: 253-259.

Oncel, T. and Biyikoglu, G. (2003): Neosporosis caninum in dairy cattle in Sakarya, Turkey. Uludag Univ. J. Fac. Vet. Med., 22 (1-2-3): 87-89.

Pare, J.; Thurmond, M.C.and Hietala, S.K. (1997): Neospora caninum antibodies in cows during 
pregnancy as a predictor of congenital infection and abortion. J. Parasitol. 83: 82-87.

Pfeiffer, D.U.; Williamson, N.B.; Reichel, M.P.; Wichtel, J.J. and Teague, W.R. (2002): a longitudinal study of Neospora caninum infection on a dairy farm in New Zealand. Prev. Vet. Med. 54: 11-24.

Quintanilla-Gozalo, A.; Pereira-Bueno, J.; SeijasCarballedo, A.; Costas, E. and Ortega-Mora, L.M. (2000): Observational studies in Neospora caninum infected dairy cattle: relationship infection - abortion and gestational antibody fluctuations. Int. J. Parasitol. 30: 900-906.

Rahman W.A.; Manimegalai, V.; Chandrawathani, P.; Premaalatha, B. and Zaini, C.M. (2011): Comparative seroprevalences of bovine toxoplasmosis and neosporosis in five states in Malaysia. Global Veterinaria. 6 (6): 575-578.

Rodrigues, A.A.R.; Gennari, S.M.; Aguiar, D.M.; Sreekumar, C.; Hill, D.E.; Miska, K.B.; Vianna, M.C.B. and Dubey, J.P. (2004): Shedding of Neospora caninum oocysts by dogs fed tissues from naturally infected water buffaloes (Bubalus bubalis) from Brazil. Veterinary Parasitology, 124: 139-150.

Schares, G.; Rauser, M.; Söndgen, P.; Rehberg, P.; Bärwald, A.; Dubey, J.P.; Edelhofer, R. and
Conraths, F.J. (2000): Use of purified tachyzoite surface antigen p38 in an ELISA to diagnose bovine neosporosis. Int. J. Parasitol. 30: 1123-1130.

Simsek, S.; Utuk, A.E.; Koroglu, E. and Dumanli, N. (2008): Seroprevalence of Neospora caninum in repeat breeder dairy cow in Turkey .Arch Tierz Dummorstorf. 51 (2): 143-148.

Thurmond, M.C. and Hietala, S.K .(1997): Effect of congenitally acquired Neospora caninum infection on risk of abortion and subsequent abortions in dairy cattle. Am. J. Vet. Res. 58: 1381-1385.

Von Blumroder, D.; Schares, G.; Norton, R.; Williams, D.J.; Esteban-Redondo, I.; Wright, S.; Bjorkman, C.; Frossling, J.; Risco-Castillo, V.; Fernandez-Garcia, A.; Ortega-Mora, L.M.; Sager, H.; Hemphill, A.; van Maanen, C.; Wouda, W. and Conraths, F.J. (2004): Comparison and standardization of serological methods for the diagnosis of Neospora caninum infection in bovines. Vet. Parasitol. 120: 11-22.

Wouda, W.; Moen, A.R. and Schukken, Y.H. (1998): Abortion risk in progeny of cows after a Neospora caninum epidemic. Theriogenol. 49: 1311-1316.

\section{التشخيص المصلى لمرض الاجهاض البوغى (النيوسبوروسز) فى مدينة الموصل - العراق}

تم جمع 184 عينة مصل من الأبقار المحلية في مدينة الموصل ، العراق للتشخيص المصلي لداء الإجهاض البو البولي الجديد (النيوسبوروسز)

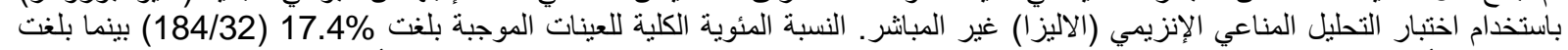
نسبة تواجد أضداد البوغ الكلابي الجديد

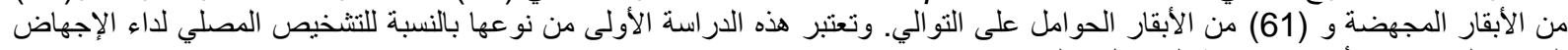
البوغي الجديد في الأبقار في مدينة الموصل الابفر ، العر اق. 